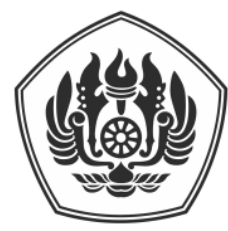

Padjadjaran Journal of International Law

ISSN: 2549-2152, EISSN: 2549-1296

Volume 3, Number 2, June 2019

\title{
Fomer Child Soldiers: Product of Armed Conflicts and How the International Criminal Court Fails to See Its Significance
}

\author{
Dino Panji Pananjung, ${ }^{*}$ Sigar Aji Poerana**
}

\begin{abstract}
In armed conflicts, children are often kidnapped and forced to become child soldiers, they are also given forced indoctrination (by violence and threats) and are taught to commit crimes, such as looting and murder. Disobeyed children and those who try to escape will be punished in the form of torture or even being executed in front of other children's soldiers as a lesson so others will not follow their step. When they did not serve the armed forces anymore or they grew up and no longer held child status, they were given the title of "former child soldiers". These former child soldiers might still live in rebellious environments and commit serious crimes including international crimes under jurisdiction of International Criminal Court when they grow up. This research argues whether the International Criminal Court considers the historical status of the perpetrators who are former child soldiers as mitigating factor of their punishment. The research method used is the juridical normative approach. The result of this research shows the International Criminal Court has never considered the history of international criminals as child soldiers. However, the International Criminal Court may use the consideration beside what has been regulated in Rome Statute, such as Article 21(3). This is also based on the Judge's right for discretion in the Rome Statute to adjudicate, as what we can see in the Case of Omar Khadr.

Keywords: Child Soldier, Criminal responsibility, International Criminal Court, Judgment and Sentencing, Rome Statute

\section{Mantan Tentara Anak: Produk Konflik Bersenjata dan Bagaimana Mahkamah Pidana Internasional Gagal Melihat Makna Keberadaan Mereka}

\begin{abstract}
Abstrak
Dalam konflik bersenjata, anak seringkali diculik dan dipaksa menjadi tantara anak, mereka juga didoktrin paksa (melalui kekerasan atau ancaman) serta diajakan untuk melakukan kejahatan seperti menjarah dan membunuh. Mereka yang tidak menurut dan yang mencoba melarikan diri akan dihukum dengan disiksa di hadapan para tantara anak lainnya sebagai contoh agar tidak ditiru oleh anak lainnya. Mereka disebut "mantan tantara anak" setelah tidak lagi menjadi teantara atau telah dewasa. Tidak menutup kemungkinan ketika dewasa mereka hidup dengan jiwa pemberontak dan melakukan kejahatan serius bahkan kejahatan internasional yang menjadi jurisdiksi Mahkamah Pidana Internasional. Penelitian ini membahas apakah Mahkamah Pidana Internasional mempertimbangkan riwayat seorang pelaku kejahatan internasional yang menjadi seorang mantan tentara anak untuk meringankan hukuman mereka. Metode penelitian yang

PADJADJARAN JOURNAL OF INTERNATIONAL LAW Volume 3 Number 2 Year 2019 [ISSN 2549-2152] [e-ISSN 2549-1296]

* Legal Staff at PT. Bintai Kindenko Engineering Indonesia, dino.panji@gmail.com

** Legal Researcher at HukumOnline Indonesia, sigar.poerana@gmail.com
\end{abstract}


digunakan adalah yuridis normatif. Hasil penelitian menunjukkan bahwa praktik Mahkamah Pidana Internasional tidak pernah mempertimbangkan latar belakang pelaku kejahatan internasional sebagai mantan tentara anak. Namun, Hakim Mahkamah Pidana Internasional dapat menggunakan ketentuan diluar Statuta Roma berdasarkan pasal 21(3). Hal ini juga didasari pada adanya diskresi Hakim untuk memutus dan mengadili diluar yang diatur di dalam Statuta Roma, seperti halnya Kasus Omar Khadr.

Kata Kunci: Mahkamah Pidana Internasional, Pemidanaan, Pertanggungjawaban Pidana, Statuta Roma, Tentara Anak

\section{A. INTRODUCTION}

Growing and developing in a family with happiness and compassion is the right for every child without exception. ${ }^{1}$ This right certainly cannot be obtained by children who are abducted and forced to be always ready at the forefront of an armed conflict. These children are forced to risk their lives and future not for what they must strive for in their essence. The 1989 United Nations Convention on the Rights of the Child (CRC) emphasized that in society, family is the most basic place for children. Children must be protected in the ideal spirit of the existence of the UN Charter, specifically peace, dignity, tolerance, freedom and equality. ${ }^{2}$

In 2018, Child Soldier International noted that there were at least 18 armed conflicts throughout the world where children participated in battles. In addition, around 240 million children were involved in armed conflict throughout their lives, of which 1,900 children were forcibly recruited in South Sudan for the past 6 years and 14,000 children were forcibly recruited in the Central African Republic. $^{3}$
The Children's Fund (UNICEF) stated that children who were victims of being involved in armed conflict in the past few decades consisted of 2 million dead children; 4-5 million children become mentally and physically disabled; 12 million children become homeless; more than 10 million are orphans or separated from their parents and suffer from psychological trauma. ${ }^{4}$ This armed conflict also shows that children were always in the field of armed conflicts as a part of the armed forces. ${ }^{5}$

Children, who are forcibly trapped in a cruel military environment, have no way to get out of the environment. Their condition was under strict and vicious military environment. They were forced to directly witness as their fellow child soldiers are being tortured or executed when any of them disobeyed orders. ${ }^{6}$

Child soldiers are seldom mere witnesses to violence, sadly; they are often made victims of coercive violence as well. Compared to their adult counterparts, child soldiers are far more likely to have been initially forced into military service. The reasons are complex but hardly

Paragraph 7, United Nations Convention of the Rights of the Child (UNCRC), 1990.

Ilene Cohn and Guy S. Goodwin-Gill, Child Soldier: The Role of Children in Armed Conflict, Oxford: Clarendon Press, 1997, p. 1.

Child Soldier International, "Child Soldiers International Annual Report 2017-2018", https://www.childsoldiers.org/Handlers/Download.ashx?IDMF=841fa200-9315-4e8a-9a6c-cdf63a0af22a, accessed on February 2018.

Jenny Kuper, International Law Conerning Child Civilians in Armed Conflict, Oxford: Clarendon Press, 1997, p. 1

5 Eben Kaplan, "Child Soldiers Around the World", https://www.cfr.org/backgrounder/child-soldiers-around-world, downloaded on the $28^{\text {th }}$ of January 2017 ; The Washington Post, "The zombie claim that 300,000 children are used as child soldiers," https://www.washingtonpost.com/news/fact-checker/wp/2016/01/22/the-zombie-claim-that-300000-children-are-used-as-childsoldiers/?utm term=.e8f7b5e1c8df, accessed on $7^{\text {th }}$ of February 2017; Independent, "300,000 child soldiers in front line", https://www.independent.co.uk/news/300000-child-soldiers-in-front-line-1046382.html, accessed at $7^{\text {th }}$ of February 2017; Forbes, "For Child Soldiers, Every Day Is A Living Nightmare", https://www.forbes.com/sites/realspin/2012/12/09/for-child-soldiers-everyday-is-a-living-nightmare/, accessed at $7^{\text {th }}$ of February 2017.

6 Child Soldier International, op.cit. 
Fomer Child Soldiers: Product of Armed Conflicts and How the International Criminal

counterintuitive, and the most straightforward explanation is simply put: compared to an adult, a juvenile is more easily (and cheaply) manipulated by force and the threat of force. ${ }^{7}$

One of the poignant stories dialed by the children is the story of Ishmael Beah. He is a former child soldier in an armed conflict in Sierra Leone. Based on his confession, children who were former child soldiers in Sierra Leone were forced to fight, brainwashed, forcibly drunk, and forced to kill; "shooting people with weapons is as easy as drinking water", he stated. ${ }^{8}$

Another story can be found in Congo, where Dikembe Muamba, 17 years old in 2014, has surprisingly become a Captain in the Democratic Republic of the Congo (DRC) and carried out his duties as a leader of 50 people, consisting of 30 children and 20 adults. Muamba was forced to join the DRC by his own uncle who at the time was one of the DRC leaders. Not only that, Muamba claimed to have joined in more than 45 battles. He claimed that he did not remember how many people he had killed without knowing the reason, but one of them was a 6-year-old girl who shot him when war broke out in Congo. ${ }^{9}$

Another story is also despairingly told in Sudan, where a child soldier named Immanuel Jal together with $\mathbf{4 0 0}$ other friends of child soldiers tried to escape from a cruel military environment, but unfortunately only 16 of them survived. This shows that running away from such an environment has its own 'price'. ${ }^{10}$ All forms of crime committed by

\footnotetext{
Bernd Beber and Christopher Blattman, "The Logic of Child Soldiering and Coercion", International Organization, Volume 67, Issue 1, January 2013, p. 65104;

8 CNN, "Ex-child-soldier: Shooting became just like drinking a glass of water", https://edition.cnn.com/2012/10/08/world/africa/ishma el-beah-child-soldier/index.html accessed at $8^{\text {th }}$ of February 2017; Ishmael Beah, A Long Way Gone: Memoirs of a Boy Soldier, New York: Sarah Crichton Books, 2007, p. 122.
}

these child soldiers were carried out when they were yet 18 years old, thus they could not be tried by the jurisdiction of the International Criminal Court like adults since they were children at the time of the crime and should be protected.

They were given the title of "former child soldiers" because they did not serve the armed forces anymore or they grew up and no longer held child status, so some of these former child soldiers might still live in rebellious environments, where they will naturally lose their time as a child who should have grown and developed normally since they were forced to be drunk, indoctrinated, received cruel threats, and were tortured during childhood to make them conformed with their new military environment where they commited crimes as they grew up. ${ }^{11}$

The well-being of children and the effect of involving children in battlefield are noteworthy since had from the beginning these children were not kidnapped and forced to become soldiers, they would not have become criminals. Their lives should not constantly under any threat or fear. A guilty verdict by the Court will only add to the suffering they experienced after escaping a despicable environment of armed conflicts which stole their childhood.

Dominic Ongwen, who had the background as a child soldier, was kidnapped at the age of 9 years and got indoctrinated, intoxicated, and forced to commit a

\footnotetext{
9 The New Humanitarian, "Growing up in war - the DRC's child soldiers", http://www.thenewhumanitarian.org/feature/2014/03/3 $1 /$ growing-war-drc-s-child-soldiers, accessed on $9^{\text {th }}$ of February 2017.

10 National Public Radio, "A Former Child Soldier Finds Escape, Heaven Through His Music", https://www.npr.org/sections/goatsandsoda/2015/01/29 382482527/a-former-child-soldier-finds-escape-heaventhrough-his-music, accessed at $9^{\text {th }}$ of February 2017.

11 P.W. Singers, "Caution: Children at War", Journal of the US Army War College, Volume 31, No. 4, 2002, p. 47.
} 
crime. ${ }^{12}$ However, Ongwen was not as fortunate as his friends who were rescued or escaped from these conditions; he spent the rest of his life in the Lord Resistance Army (LRA) environment and ended up being one of the leaders of the LRA forces. The-now adult Ongwen committed some of the most terrible crimes such as crimes against humanity and war crimes. These crimes make him currently the only former child soldier tried at the International Criminal Court. ${ }^{13}$

Those who are under rebel authority always follow the orders of their superiors to spread terror to civilians ranging from murder, rape, slavery, and other crimes such as war crimes and even genocide. They must do this "survival crime" since if they disobey, they will be tortured, enslaved, or even killed and so they have no other means to survive. ${ }^{14}$

Cases involving former child soldiers, such as Dominic Ongwen, really portray a common practice of involving children in the battlefield who are supposed to be protected by International Human Rights Law and International Humanitarian Law. Instead, they were presence in armed conflicts as participants and yet, the law has not regulated such involvement. There is no clear determination of child soldiers status; whether they, if ultimately involved, are treated as members of armed forces or children in armed conflicts. The article will discuss this phenomenon and the treatment given by the International Criminal Court when dealing with former child soldiers which will be compared by other national judicial decision involving child criminals. It will be then identified whether such status become a part of consideration by the Court when assessing a case involving criminals who were

12 Erin K. Baines. "Complex political perpetrators: reflections on Dominic Ongwen", The Journal of Modern African Studies, Volume 47, Issue 2, 2009. p.180

13 Ibid.

14 Michael G. Wessells, Child Soldiers: From Violence to Protection, Longdon: Harvard University Press, 2006, p. 79. under 18 years old at the time of the crime committed and also criminals who were child soldiers as they grew up and became adults.

\section{B. THE OVERVIEW OF CHILD SOLDIER}

International Conventions do not explicitly regulate the definition of children. These conventions only have regulations regarding the prohibition on the use of children in armed conflict. However, the International Criminal Court in Lubanga's decision defines child soldiers as soldiers whose age is less than 18 years old. ${ }^{15}$

In armed conflicts, children are often kidnapped and forced to become child soldiers, they are also given forced indoctrination (by violence and threats) and are taught to commit crimes, such as looting and murder. Disobeyed children and those who try to escape will be punished in the form of torture or even being executed in front of other children's soldiers as a lesson so others will not follow their step. ${ }^{16}$ Not only were they involved in armed conflict, female soldiers were also forced to serve their superiors, become sex slaves, or even "concubines" for their superiors' children to become soldiers again. ${ }^{17}$

\section{Voluntary and Involuntary Child Soldier}

Generally, there are two conditions relating to the involvement of children in war, namely those who are involved because of their own wishes (voluntarily) or by means of forced (involuntary). Alice Schmidt in her research stated that there were some differences between child soldiers who were voluntary and not voluntary.

15 See ICC, Presecutor v. Thomas Lubanga Dyilo (Trial Chamber), Reparation and Compensation, 2012, para. 574.

16 Alcinda Honwana, Child Soldiers in Africa, Pennsylvania: University of Pennsylvania Press, 2005, p. 70.

17 Michael G. Wessells, op.cit, p. 96. 
Fomer Child Soldiers: Product of Armed Conflicts and How the International Criminal

\section{a. Voluntary Child Soldier}

Voluntary child soldier is children who join armed forced voluntarily, ${ }^{18}$ but it still a debate among experts, considering that their volunteerism still has reasons that they cannot avoid. The condition of child soldiers in Sierra Leone shows that several children survived the attack of the rebel army. The rebels not only destroyed their homes, but also the Rebels killed their families. Children who survived the raid chose to join the national army to stay alive, take revenge, or for other reasons which were their last choice and forced them to join the armed forces and fight on the battlefield.

\section{b. Involuntary Child Soldier}

In contrast to those who volunteer to become soldiers, the involuntary child soldiers are those who are forced or kidnapped from their families to be used as soldiers or servants of an army..$^{19}$ Their first task is usually to kill their own family members. With the feeling of guilt and loss of their family members, eventually they have no other choice to survive other than following the soldiers who come to them with their new way of life and "home". ${ }^{20}$

c. Determinism Criminology: Former Involuntary Child as VictimPerpetrator

The status of "victims" described in this article are those who have become victims of a crime who committed crimes later in the future; and someone who, as a result of being a victim to a crime committed against him/her, commits the same crime as or other crime. Currently, child soldiers can only be seen as victims, which reflects upon the lack of international instruments that regulate or prohibit the persecution of children who have committed crimes. The victims who became criminals are not only limited to former child soldiers who commit crimes; the condition can occur outside of ar med conflicts, even in a modern-day city. ${ }^{21}$

Determinism is defined as a doctrine which confirms that an event occurs because of necessity and certainty so that it is unavoidable. ${ }^{22}$ This definition then narrows the concept of "causal determinism" which translates to: a current event is entirely the result of previous events. In its continuity as a chain of events, this definition is divided into several points of view, for example depending on the chain of determinism or how strong the determinism is. ${ }^{23}$ This notion believe that if someone did a crime, it must be caused (determined) by past events. ${ }^{24}$ This school sees that an event occurred in the present has always been a result of something had happened in the past. What the International Criminal Court should see is that any former child soldier living presently, whether they have
Alice Schmidt, "Volunteer Child Soldiers as Reality: A Development Issue for Africa", New School Economic Review, Volume 2(1), 2007, p. 51.

19 David M. Rosen, op.cit, p. 61.

20 James H. Monach, Childless: No Choice: The Experience of Involuntary Childlessness, London: Routledge, 2006, p. 58.
21 Ronald B. Flowers, Children and Criminality: The Child as Victim and Perpetrator, Connecticut: Greenwood Press, p. 78

22 Susanne Bobzien, Determinism and Freedom in Stoic Philosophy, New York: Oxford Press University, 1998, p. 33.

23 Ibid.

24 Ibid. 
had become perpetrator or not is a result of the forced abduction and indoctrination towards them, which means that these poor former child soldier would not become a villain soldier neither a perpetrator if they had not been captured in the past.

The children forcedly employed by these ruthless soldiers often constrained to perform rites of initiation. Indeed, even within these groups, children are more likely than adults to be subject to such rites Recruits are sometimes made to commit acts that are both traumatic and identity-transforming, like the murder of a family member or the defilement of a neighbor's corpse. It is worth considering this phenomenon in light of the preceding discussion about appetitive aggression. After all, if participating in violence is part of the price of admission to an armed group, recruits may be on a trajectory toward increased levels of appetitive aggression even before they begin participating in 'official' hostilities as part of the group. Additionally, these initiation rites can serve to dissolve ties between the child soldiers and their social habitats, which is a particularly hazardous outcome for young people. Even if adults and children were forced with equal frequency to perform similarly horrific rites of initiation-which they are not, the evidence indicates-an adult is more likely to have already established strong bonds within their community, which even a deep violation of that community's norms will be hard to break. Contrary, child soldiers who are forced to kill a family member or assist in torturing a prisoner may find themselves cut off from the communities that raised them, beyond the hope of reconciliation or return. The more successful and permanent the recruit's traumatic disconnection from their community, and the earlier that separation occurs, the more remote are the recruit's chances are for subsequently qualifying as a responsible agent for their new group. ${ }^{25}$

In combination with initiation rites, armed groups generally use forcible indoctrination to keep their child soldier under control. This indoctrination can take the form of misleading political propaganda, selective suppression of information or access thereto-for instance, seizing all radios within the armed group once leaders learned that offers of amnesty were being broadcast-or spiritual or religious brainwashing. ${ }^{26}$

These measures do not merely affect a child's mind with some misleading information or allegiance feelings; they serve to bring the child soldiers' habits of thinking, acting, and making decisions in line with the priorities of the military leaders who give them command. Also, indoctrination measures are not unique to child soldier populations, but child soldiers are significantly more likely to be the subject to such measures than their adult counterparts for the intuitive reason, borne out by the available data, that children are more vulnerable to this 
Fomer Child Soldiers: Product of Armed Conflicts and How the International Criminal

\section{Court Fails to See Its Significance}

kind of influence. From the strategic perspective of these leaders, the relative ease of indoctrinating children can offset their comparative ineffectiveness as troops. Indoctrination is not a spontaneous by-product of conflicts involving child combatants; it is rather a purposely adopted strategy to produce allegiance, fear, and unquestioning obedience in their youngest recruits. ${ }^{27}$

Such conditions applied to the case of Ongwen, His mind in the present, or in the time that he allegedly committed the crimes was a cumulative aftermath effect he received since he was very young from the time he was abducted by the LRA. The author believes that Ongwen, or any other perpetrators (if any) who has the history as a victim of abduction by criminals and forcibly grew up with such group would have had different path if they did not.

\section{State Obligation to Protect Children in Armed Conflict}

There are child's specific rights or special rights for children that require the involvement of States in its fulfillment. Jhon Eekelaar explains that the emergence of human rights regime specifically those which are intended for children was motivated by at least three things. ${ }^{28}$ First, children have basic interest or the most basic needs to be loved, accompanied, and protected. ${ }^{29}$ Fulfilling these basic needs requires a physical, emotional, and intellectual approach from those responsible for the

27 Tyler Fagan, ibid. p. 285.

28 Carter Dillard, "Prospective Parents and the Children's Rights Convention", American University International Law Review, Volume 25, Issue 3, 2010, p. 499-500.

29 Ibid. child ${ }^{30}$ Based on these considerations, States guarantee that every child has a parent or guardian in the context of civil rights, for example, the State also guarantees that the child has the right not to be tortured and they are not a subject of human trafficking and sexual crime. Various inherent civil rights bestowed upon children also instigate punishment for the offenders.

Second, children have interests or the need to develop their capacity and potential. ${ }^{31}$ This need is driven by the guarantee of children's rights to education, health, healthy food intake, and even recreation. ${ }^{32}$ The need for a child to develop requires an active role from the State, such as the provision of free mandatory education, free immunization or free health insurance for children from poor families.

Third, children have autonomy interest, it means children can only take action on their own will which requires the presence of the State in addressing this. For example, the child's right to obtain a fair legal process when he or she is suspected of committing a crime. ${ }^{33} \mathrm{In}$ many countries, considering the psychological development of children who are different from adults, legal proceeding for children is usually distinguishable from the adult's, the punishment for children who commit crimes is also usually lighter compared with the adult.

Legal instruments regarding the recruitment of child soldiers are also found in the International Convention on the Right of the Child (hereinafter $C R C$ ) which was signed on November 20, 1989, 
and came into force on September 2, 1990. The legal provisions governing the involvement of children in armed conflict are only contained in one article; Article 38 which contains various State obligations to not recruit children under the age of 15 years and provide protection for children affected by armed conflict. Further, it only mimic Article 77 paragraph (2) Additional Protocol I of 1977 (hereinafter AP /). ${ }^{34}$ Both CRC and AP I do not provide a legal framework in terms of children who ultimately, although against the law, involved in armed conflicts and the status or circumstances which should be considered in relation with their crimes. Both international conventions regulate States' obligation to ensure that under18-years-old children will not directly involved in hostilities. AP I also dictates an obligation upon State parties to not recruit those who have not reached the age of 18 into their armed forces. This provision is an improvement compared with the CRC which only defines and limits the age of children who may not be recruited for armed forces to be under $15 .^{35}$

Regarding voluntary recruitment, State parties are bound by the minimum age in recruiting members of armed forces. The next provision dictates that the recruitment has to receive approval from a parent or guardian. However, what needs to be the main focus is that the regulation on voluntary recruitment does not apply to military academies. This prohibition does not only apply to the armed forces of State parties, but also applies to other armed groups and in all situations. ${ }^{36}$

In this case, there is no specific provision regarding penalties if the State fails to protect children who are then recruited to become child soldiers. However, the practice of countries such as Canada, Sierra Leone, Central Africa, the United Kingdom, and many other countries show that States should provide rehabilitation to, at least, reduce and restore these former child soldier lives. ${ }^{37}$

The CRC also mandates the application of "the best interest of the child". The principle states that in all actions relating to children, the best interests of the child must be a primary consideration in making decisions or policies, ${ }^{38}$ meaning that decisions made by legislative, executive and judicial bodies must always consider the impact of their decisions on the interests and rights of the well-being of the children.

\section{CASE OF FORMER CHILD SOLDIER: VICTIM OR PERPETRATOR?}

1. Case of Prosecutor v. Dominic Ongwen Dominic Ongwen is currently the only former child soldier on trial at the International Criminal Court. The crimes that he committed are nothing but a causality of what happened to him when he was a child. When he was 9 years old, Ongwen was kidnapped by LRA when he was leaving from school. His house and his village were attacked by the LRA,

6 William Sweet, op.cit.

37 Samuel O. Okpaku, Essentials of Global Mental Health, New York: Cambridge University Press, 2014, p. 219.

38 Supriyadi W. Eddyono, S.H, Seri Bahan Bacaan Kursus HAM untuk Pengacara XI Tahun 2007, Jakarta: Lembaga Studi and Advokasi Masyarakat, 2007, p. 3 
Fomer Child Soldiers: Product of Armed Conflicts and How the International Criminal

\section{Court Fails to See Its Significance}

Ongwen had no other choice but to obey ordered by the LRA. ${ }^{39}$

While kidnapped and under the control of the LRA led by Joseph Cony, Ongwen and other kidnapped children were forced to become brutal soldiers through forced indoctrination (brainwashing) so that they were unable to distinguish between what was right and wrong. ${ }^{40}$ When they were still under 18 , they were forced to burn villages, pillages, mutilation, and kidnapping. ${ }^{41}$ These action were done so the LRA could spread terror and increase its military strength. These horrible deeds was forced to be carried out by the child soldiers in order to make a life, since if they disobeyed or tried to escape, they would be punished in the form of torture or even execution by LRA leaders in the presence of other child soldiers so it would spread fear among them. ${ }^{42}$

In addition, besides being forced to commit crimes, child soldiers are also intended to be used as real soldiers who fight in armed conflicts. In order to improve their adrenaline and to eliminate fear, the LRA then forced the child soldiers to consume addictive substances in the form of narcotics or alcoholic beverages that they believed as adrenaline relievers; in other words, the child soldiers were under forced intoxication. ${ }^{43}$

Over time, the surviving child soldiers grew up, including Dominic Ongwen who was later trusted by Kony to become one

39 Mark A. Dumblr, Reimagining Child Soldiers in International Law and Policy, Oxford: Oxford University Press, 2012, p. 91.

40 See ICC, Prosecutor v. Dominic Ongwen (Pre-Trial Chamber), Decision on the confirmation of charges 2016, para 25.

41 Sarah Kihika, "The Complex Reality beyond the Trial of Dominic Ongwen", https://www.ictj.org/news/complexicc-ongwen accessed on $3^{\text {rd }}$ of September 2018.

42 Sonja C. Grover, Child Soldier Victims of Genocidal Forcible Transfer: Exonerating Child Soldiers Charged with Grave of the five LRA leaders (including Kony) because of his courage and brutality in carrying out Kony's orders. The crimes that he conducted during the time he was a child soldier were still a part of his routine as a leader, such as rampant killings, kidnapping, raping, and burning villages in Uganda. ${ }^{44}$

The death of Vincent Otti (one of the senior commanders at the LRA) made Ongwen then occupies Vincent's position at the LRA starting in $2012 .{ }^{45}$ On $3^{\text {rd }}$ January 2015 Ongwen surrendered to the Central African Republic army, two days later he was taken over by American soldiers who were on duty to help fight the LRA and then American soldier took Ongwen to their base in Obo, central Africa. Finally Ongwen ended in Den Hag under the supervision of the International Criminal Court since January 17, 2017. Three of the five LRA leaders were declared dead, leaving the remaining Ongwen and Kony. Ongwen Succeed being taken care by "correct" handler at International Criminal Court, while Kony still could not be found. ${ }^{46}$

Seeing a court ruling outside the International Criminal Court, there is almost no verdict that considers the history of a former child soldier neither to reduce nor to exclude criminal liability. The only decision that involved an accused who was a former child soldier is a verdict in the Canadian National Court that will be discussed on the next section.

Conflict-related International Crimes, Ontario: Springer, 2012, p. 249.

$43 \quad$ Ibid, p. 104.

44 Luke Moffett, Justice for Victims before the International Criminal Court, London: Routledge, 2014, p. 204.

45 Chimpreports, "KCC - Cosmos De Bafia (Cameroon) ticketing info", https://chimpreports.com/kcc-cosmos-debafia-cameroon-ticketing-info/ accessed at $9^{\text {th }}$ of September 2018.

$46 \quad$ Luke Moffett, ibid, p. 306. 
2. USA v. Omar Khadr/ Prime Minister of Canada v. Omar Khadr

The "War on Terror" policy of the United States which was adopted during the administration of President George W. Bush is still controversial until now. Most of the policy controversies are related to the occurrence of various violations of International Humanitarian Law in relation with the treatment of prisoners. Most of the prisoners are suspected terrorists who were put in custody at the Guantanamo Prison Complex. At the end of his administration, the President only had very little evidence to show the world that justice had been achieved with his policy in curbing terrorism cases since the occurrence of the 9/11 Tragedy. ${ }^{47}$ With little evidence of justice achieved by Bush, the reason why he was so compelling to try prisoners by using his own Military Commission was that many prisoners were found guilty and their policies were considered successful.

One of the prisoners being tried was Omar Khadr, a child soldier accused of being a terrorist. Khadr was tried in the United States and detained in Guantanamo until 2012. International community argued that this is very unfortunate and it's a misfortune that befell Khadr. Khadr was tortured and treated cruelly as well as did not went under fair trial. ${ }^{48}$ Khadr was transferred from a special prison for terrorism in Guantanamo, Cuba to Alberta, Canada in 2012.

Shadia B. Drudy stated that Omar's first misfortune was to be born in a family that had a radical interpretation of

47 Michelle Snephard, Guantanamo's Child: The Untold Story of Omar Khadr, Ontario: John Wiley \& Sons Canada Ltd, 2008, p. 5.

48 JURIST Legal News, “The Omar Khadr Case: Redefining War Crimes", http://jurist.law.pitt.edu/omar-khadr-caseredefining-war-crimes.php, accessed at 30 ${ }^{\text {th }}$ June 2018. fundamentalism about Islam. Omar Khadr was born on September 19, 1986 in Toronto, Canada. Omar's father, Ahmed Khadr immigrated to Canada from Egypt in 1977. Khadr's father was associated with radical Islamic groups in Pakistan and Afghanistan. In Pakistan and Afghanistan, Omar's family often move from one place to another. ${ }^{49}$ It was Khadr's father who threw him into the world of terrorist networks in Afghanistan by forcibly signing him up for military training and assembling bombs, enforcing doctrines of radicalism, and claiming his rights as a child who should grow up with a proper family. ${ }^{50}$

In July 27, 2002, in the Khost area of Afghanistan, the building where Omar Khadr lived was attacked by a combination of Special Forces from the United States (US Special Force) and about 100 Afghan soldiers. The gunfire took place for several hours using an AK47 , grenade and finally ended with the drop of a 500-pound bomb, equivalent to 250 kilograms from the air towards the building. After the attack was done, most of the buildings were destroyed and most of the people around the building died or were seriously injured.

American forces ordered mop up team to sweep the location shortly after the bomb was dropped. During the sweeping, Omar Khadr and one other person were seriously injured. Seeing that there were survivors, one of the troops shot Khadr, so he sustained two gunshot wounds on his back, while one man near Khadr died. At that time, it was alleged that either Omar Khadr or the unknown

49 Shadia B. Drury, "Omar Khadr and the Perils of Canadian Multiculturalism" in Omar Khadr, Oh Canada, Ontario: Mc.Gill - Queens University Press, 2012, p.376.

50 Ibid. 
Fomer Child Soldiers: Product of Armed Conflicts and How the International Criminal

man had thrown a grenade and part of a grenade fragment wounded a member of the United States soldier named Sergeant Christopher Speer. Khadr, who was miraculously still alive after being shot twice by the American forces, arrested and detained at Bagram Air Base for three months and then transferred to Guantanamo where he lived there for nearly ten years. During his imprisonment at Guantanamo, Omar Khadr received various methods of torture while being interrogated. However, Khadr always consistently denied that he had thrown the grenade, he swore he did not throw the grenade. Sadly, none of the US forces believed and reviewed the evidence and so the torture continued. ${ }^{51}$

The Government of Canada in the end apologized to Khadr and even provided him restitution as their prior failure to fulfill their citizen's right.

\section{JUDGE'S CONSIDERATION IN IMPOSING CRIMINAL OFFENSE AGAINST AN INTERNATIONAL CRIMINAL WHO HAS A BACKGROUND AS A CHILD SOLDIER}

The International Criminal Court has not yet decided to exclude an international criminal who has a history of being a former child soldier or an international criminal who has been a victim of other crimes. But, at the moment, the ICCis following up on Dominic Ongwen's case, which is the only case with the perpetrator who has a history of being a child soldier. ${ }^{52}$ However, Ongwen is not the only international criminal who has a

51 Janice Williamson, Omar Khadr, Oh Canada, Ithaca: McGillQueen's University Press, 2012, p. 71.

52 Francis Ssekandi and Netsanet Tesfay, "Engendered Discontent: The International Criminal Court in Africa", Georgetown Journal of International Affairs: Vol XVIII, No.1, 2017, p. 86.

53 M. Cherif Bassiouni and William A. Schabas, The Legislative History of the International Criminal Court, New York: Transnational Publishers, Inc., 2005, p. 451. background as a former child soldier, this assumption is based on the number of child soldiers spread throughout the world in the past decade.

In determining whether someone is guilty or not, and determining the weight or severity of a sentence, the ICC Judges must look at certain situations. In this case, as discussed previously, in deciding a case the Court will consider the gravity of the crime and the individual conditions set out in Article 77 and Article 78 of the Rome Statute concerning Penalties. ${ }^{53}$

The following is the Ongwen case that the author will try to analyze using formal standards at the International Criminal Court:

\section{Gravity of the Crime}

In determining how severe the level of crime committed by the accused, the judge saw from the facts and evidence presented at the trial. The facts and evidence will be obtained from the Public Prosecutor and Legal Counsel, as well as the testimony and participation of victims' representatives, which refers to the number of victims, the form of damage done, circumstances against the law, time and place.

Gravity of the crime is one of the elements in article 17 (1) (d) of the Rome Statute on Admissibility. In this case the Court has the standard cited in the case of Lubing, namely: ${ }^{54}$

...any case arising from an
investigation before the Court
will meet the gravity threshold
provided for in article $17(I)(d)$ of

54 See ICC, Prosecutor v. Lubanga (Pre-Trial Chamber), Decision concerning Pre-Trial Chamber I's Decision of 10 February 2006 and the Incorporation of Documents into the Record of the Case against Mr Thomas Lubanga Dyilo, 2006, paras. 42- 60; See ICC, Prosecutor v. Abu Garda (PreTrial Chamber), Decision on the Confirmation of Charges, 2010, para. 31. 
the Statute if the following

three questions can be answered affirmatively:

1. Is the conduct which is the object of a case systematic or large scale (due consideration should also be given to the social alarm caused to the international community by the relevant type of conduct);

2. Considering the position of the relevant person in the State entity, organization or armed group to which he belongs, can it be considered that such person falls within the category of most senior leaders of the situation under investigation? and

3. Does the relevant person fall within the category of most senior leaders suspected of being most responsible, considering (1) the role played by the relevant person through acts or omissions when the State entities, organizations or armed groups to which he belongs commit systematic or large-scale crime within the jurisdiction of the Court; and (2) the role played by such State entities, organizations or armed groups in the overall commission of crimes within

55 Interview with Judge Raul C. Pangalangan on 24 July 2018, 18.00 WIB in Bandung, Indonesia

56 Women's Initiatives for Gender Justice, "First ICC Trial in the Uganda Situation the Prosecutor $v$. Dominic Ongwen 5 December 2016", https://4genderjustice.org/pub/FirstICC-Trial-in-Uganda-Situation-Statement.pdf accessed at 21st of March 2018. the jurisdiction of the Court

in the relevant situation?

Raul C. Pangalangan who acted as Judge in the Ongwen case stated that this case was a case that met the gravity of the crime criteria. ${ }^{55} \mathrm{As}$ a defendant, Ongwen was at least ranked second with the highest number of victims, and more than 4,500 victims had been given the right to be able to participate in the trial. ${ }^{56}$ With 70 counts filed against him including war crimes and crimes against humanity which claimed more than 100,000 lives and the kidnapping of more than 60,000 children to be forcibly used as soldiers; Ongwen's role was very dominant in those following acts. ${ }^{57}$ Raul added Ongwen's participation was very marginal, he was directly involved in the crimes committed by the LRA. ${ }^{58}$ It means, according to Raul, the gravity of crimes includes the number of victims, the involvement of the accused, and the amounts. This shows that the gravity of the crime in the Ongwen case has been met, but the final verdict of this case cannot ascertain whether with such gravity of the crime, it will incriminate the sentence or exclude criminal responsibility due to his status as former child soldier who suffers from crimes done towards him.

\section{Defendant's Personal Situation}

The next criterion for the judge to see is the defendant's personal situation. There are certain circumstances for the Court to determine this situation, such as age, health, character and family responsibilities. In addition, there is also

\footnotetext{
57 Sarah Kihika Kasande and Virginie Ladisch, "The Complex Reality Beyond the Trial of Dominic Ongwen", https://www.ictj.org/news/complex-icc-ongwen. Accessed on 25 th of March 2018.

58 Interview with Judge Raul C. Pangalangan, op. cit.
} 
Fomer Child Soldiers: Product of Armed Conflicts and How the International Criminal

the guilty feeling of the perpetrators and the perpetrators' cooperation during the trial. ${ }^{59}$

In this section, a former child soldier history is likely not to be considered by the judge, this can be seen from the decision of the International Criminal Court Confirmation of Charges. In its confirmation, the ICC did not consider Ongwen as one of the victims of the armed conflict that had occurred in Uganda, ${ }^{60}$ however the Ongwen Legal Counsel team still tried to touch the judge's conscience and ensure that Ongwen is also a victim.

If it is based only on the formal framework of the ICC's decision, the decision will include the following matters which have nothing to do with the crimes committed by former child soldiers, including: ${ }^{61}$

\section{a. Age, background, education, socioeconomic situation in the defendant's detention}

Ongwen, who is now 43 years old, has no educational background since his kidnapping occured 33 years ago, while he was 10 . In confirming the accusations against Ongwen, the crimes committed from 2001 to 2003 meant that he was 26 to 28 years old. ${ }^{62}$ Based on this age, Ongwen belongs to the category of adults according to Article 26 of the Rome Statute and thus, the Court has

59 M. Cherif Bashounia and Wiliam Schabas, loc.cit.

60 See ICC, Prosecutor v. Dominic Ongwen (Pre-Trial Chamber), Decision on the confirmation of charges against Dominic Ongwen, 2016, para. 120.

61 The Pattern of International Criminal court in presenting the Judgement and Sentencing

62 See ICC, Prosecutor v. Dominic Ongwen (Pre-Trial Chamber), Decision on the confirmation of charges against Dominic Ongwen, 2016, para. 121.

63 See ICC, Prosecutor v. Dominic Ongwen (Pre-Trial Chamber), Decision on the confirmation of charges against Dominic Ongwen, 2016, para. 150 jurisdiction to proceed the case to trial.

Ongwen was forced to leave his normal life with his family and could no longer saw his friends or relatives in school or at home. ${ }^{63}$ Ongwen was detained for one and a half years in the Den Hag, far from his hometown in Uganda, after he surrendered himself to the International Criminal Court. ${ }^{64}$

b. Confession of Guilt

Confession of Guilt is a sense of remorse and guilt from the perpetrators of international crimes to the victims for the crimes they committed. Dominic Ongwen surrendered to US troops in the Central African Republic and was later handed over to the ICC before the Public Prosecutor of the International Criminal Court where Ongwen admitted his crimes of massacring civilians. ${ }^{65}$ This can be directly considered by the judge that the defendant regrets his actions. In the trial at the International Criminal Court, the plea bargaining is not explicitly stated, but the judge must objectively assess and consider the decision based on these conditions in accordance with the RPE. ${ }^{66}$ In the end, the guilty plea is not specifically related to a person's history as a former child soldier, but whether or not the remorse of the defendant will generally be considered by the Judge.

64 Daily Monitor, "Wife, Children to Visit Ongwen," http://www.monitor.co.ug/News/National/Wifechildren-visit-Ongwen/688334-3479100 va6mb7z/index.html. Accessed at $28^{\text {th }}$ of March 2018.

65 See ICC, Prosecutor v. Dominic Ongwen (Trial Chamber), Statement of the Prosecutor of the International Criminal Court, Fatou Bensouda, at the opening of Trial in the case against Dominic Ongwen, 2016.

66 Jenialontcheva Turner, "Plea Bargaining and International Criminal Justice", The University of the Pacific Law Review, Vol. 48, p. 238. 


\section{c. The Defendant's Cooperation during the trial}

Ongwen was once one of the fugitives of the ICC right after his chief commander, Joseph Kony. ${ }^{67}$ The surrender of Ongwen and its participation in the trial was considered as cooperation that facilitated the Court in providing justice for victims of the armed conflict in Uganda. The writer has not been able to assess whether this matters later becomes one of the judges' considerations in the final decision later. Even so, there is no certainty about how Ongwen behaved at the trial but his presence and participation before the International Criminal Court surely offers international society an example of pursuing justice.

\section{$d$. Regret and sympathy for the victim}

Dominic Ongwen in his trial stated that he did not understand the indictment filed on him, but he regrets and fells empathy to see the victims brought to trial due to his bad deed under Kony's command. ${ }^{68}$ This statement was received by the Judge in consideration of appeals to the previous Pre-Trial Chamber. ${ }^{69}$

\section{Perpetrator's Culpability of Conduct}

Rules 145 RPE the International Criminal Court provides other conditions in delivering verdicts for judgments, such as: the accused's inclusion and criminal

67 The National Counter Terrorism Center, Counter Terrorism 2016 Calendar, United States Counter Terrorism Center, p. 86.

68 See ICC, Prosecutor v. Dominic Ongwen (Trial Chamber), Prosecution's Response to "Defense Request for Leave to Appeal the Oral Decision of 6 December 2016 on Mr Ongwen's Understanding of the Nature of the Charges", 2016, p. 6

69 Ibid.

70 ICC, "ICC Pre-Trial Chamber II confirms the charges against Dominic Ongwen and commits him to trial", liability, the intent of the defendant, and in certain conditions, the time and purpose of the defendant's deed.

\section{a. Inclusion and criminal responsibility of the perpetrator}

Confirmation Charges by the International Criminal Court adjudged that Ongwen is responsible under Article 25 (3) (a) as a direct criminal and perpetrators of indirect participation in crimes, Article 25 (3) (b) of ordering, Article 25 (3) (d) (i) and (ii), and Article 28 (a) as the Commander's Accountability. ${ }^{70}$

The ICTY is very concerned in dissecting "participation in committing crimes" as not only as a form of responsibility, but also in formulating punishment. $^{71}$ In the case of the Vasiljevic, ICTY stated that "aiding and abetting is a form of responsibility which generally warrants a lower sentence than what is appropriate for responsibility as a coperpetrator". ${ }^{72}$ The difference between this model is it is no longer in the form of description, but also the severity of a criminal responsibility. The essential principle of this statement is that committing a crime has a greater degree of criminal responsibility and is given a greater sentence than aiding a crime. ${ }^{73}$

Being a perpetrator of international crimes is often formed by the cooperation of a group of

https://www.icc-cpi.int/Pages/item.aspx?name=pr1202 accessed on $23^{\text {rd }}$ of March 2018.

71 Mariam Jikia, "Individual Criminal Responsibility According to Article 25 of ICC Statute", Scientific-Practical and Reviewed Journal "Justice", Vol. 3, 2008, p. 4.

72 See ICTY, Prosecutor v. Vasiljevic (Appeals Chamber), Judgment, 2004, para. 182; ICTY, Prosecutor v. Krstic (Appeals Chamber), Judgment, 2004, para. 268

73 Mariam, op.cit. 
Fomer Child Soldiers: Product of Armed Conflicts and How the International Criminal

\section{Court Fails to See Its Significance}

people. This means that the level of errors in international criminal law is more essential compared to other legal systems. Previously, it was explained and it must be understood that we do not only see descriptive concepts to determine criminal liability individually, but also an indicator of the level of individual error, so that it can be used to assist judges in determining punishment ${ }^{74}$ Besides, Ongwen was also charged with accountability as a commander in which case in the case of Kunarac, the judge stated that "the criminal culpability of leading others is higher than those who follow. ${ }^{175}$

In the Prosecution's Pre-Trial Brief in the case of Dominic Ongwen, the ICC mentioned in detail according to witnesses and evidence that Ongwen participated in crimes with the LRA in Uganda. ${ }^{76}$ Ongwen's inclusion above was a result of Kony's ${ }^{77}$ treatment during his time as a child soldier in LRA; his current rank in the LRA makes him one of those former child soldier who became criminals. The existence of children as Ongwen's subordinates shows that involving children as members of armed forces is a cycle where someone who used to be a child soldier will eventually search for children to be made as his subordinates, likewise to what happened to Ongwen. Participation to a crime will obviously incriminate Ongwen during the proceeding before the Court but the author sees that this

Ibid.

75 See ICTY, Prosecutor v. Dragoljub Kunarac, Radomir Kovac \& Zoran Vuković (Trial Chamber) Judgment, 2001, para. 863.

76 See ICC, Prosecutor v. Dominic Ongwen (Pre-Trial Chamber), Defence Request for Leave to Appeal the Oral Decision of 6 December 2016 on Mr Ongwen's cycle exists since someone firstly initiated it and Ongwen would not become a criminal if he had not been kidnapped; the risk is now being faced by child soldiers who currently are going through this cycle as victims.

\section{b. Intention, Time and Purpose}

Living in a military environment and in a state of armed conflict is not what children wanted, including Ongwen. ${ }^{78}$ They were in a state of being forced to follow orders without having a choice but to obey to those who have power in their environment.

For Ongwen, survival is the only reason for him to hope he can return to his original environment with his family. This can at least prove that Ongwen's initial intention to be in the LRA and to take part in all activities including the LRA's military activities was to survive, pretend to be submissive and obedient is his daily life. ${ }^{79}$ The scene of torture and execution of other child soldiers was inevitable; the attempt to escape was lost to the threat that was so great.

For many years Ongwen lived his life and did terrible deeds he was forced to do, making him used to doing crimes. Ongwen's promotion in the military ranks to become one of the LRA Leaders is considered as gift for his loyalty and cruelty in carrying out operations according to Kony's and his collegues' orders. ${ }^{80}$

Based on the provisions contained in the Statute and the RPE, there is no obligation for judges to consider the

\footnotetext{
Understanding of the Nature of the Charges, 2016, para. 67. 
background of the perpetrators who have been victims to a crime (such as child soldiers). However, the need to examine such possibility exists in practice in national law; there are cases where a person who has been a child soldier is suspected of committing a crime

In other courts, there are several similar cases where someone who was once forced to become a child soldier was later suspected of committing international crimes. They Are Muhammad Jawad and Omar Khadr, both detained and charged with war crimes in the United States Military Court at Guantanamo Bay.

Omar Khadr, who is currently 31 years old, was 15 years old when he was detained and seriously injured from gun fire in Afghanistan in 2002. He spent one third of his life at Guantanamo. He admitted he was guilty on October 25, 2010 of murder, attempted murder as war crimes, conspiracy to commit terrorism, providing material assistance for terrorism, espionage, and sentenced to a maximum of eight years in prison. He accepted the sentence with the explanation that after November 2011 he would go to Canada (where his parents lived) to resolve the remainder of his sentence. ${ }^{81}$

The Americans charged Khadr after he allegedly threw grenades and killing Christopher Speer and two other American soldiers. Although Khadr was underage, America refused

81 Canada (Prime Minister) v. Omar Khadr, Decision of the Canadian Supreme Court, 1 S.C.R. 44, 2010, para. 1.

82 Ibid.

83 Human Right Watch, "United States of America: Compliance with the Optional Protocol to the Convention on the Rights of the Child on the involvement of children in armed conflict", https://www.hrw.org/sites/default/files/supporting reso to apply the standard of justice for teenager that was universally recognized in this case, Khadr was detained and treated as adults. ${ }^{82}$

Because it was difficult to get evidence to try Khadr, America offered a plea bargain to provide a reduction in sentences against Khadr. The legal proceeding was lengthy and problematic in America, not only because America did not recognize his status as a teenager and ignored their obligation to provide rehabilitation for him, but also because his actions have not been considered a violation of the law of war. Punishing him as an adult would make a drastic reduction of the universal understanding of the law of war and yet punishing him as a former child soldier for such crimes is far more disturbing. ${ }^{83}$

Finally, in 2012, Khadr was transferred to Canada with the aim of completing his sentence, but the Canadian Government saw that there was something wrong with the legal process in America. Finally, Canada decided to rehabilitate Khadr and provide compensation. According to the Government of Canada, not only is the legal process was incorrect, but also punishing someone who was also a victim (child soldier) is also not justified ${ }^{84}$ Likewise with Jawad who was later released by the United States Military Court because it was believed that he was in a state of forced intoxication while committed his alleged crimes. In addition, Jawad's

urces/us opac review - 2017 hrw submission.pdf downloaded at 15 of April 2018.

84 Tony Navaneelan and Kate Oja, "The United States v. Omar Khadr, Pre-Trial Observation Report," https://www.law.utoronto.ca/documents/ihrp/Khadr Pre-Trial Observation Report FINAL March 2009.pdf accessed at $22^{\text {nd }}$ of October, 2018. 
Fomer Child Soldiers: Product of Armed Conflicts and How the International Criminal

\section{Court Fails to See Its Significance}

legal counsel also insisted that Jawad has a history as a child soldier. ${ }^{85}$

Canada as a country considers itself to have failed to fulfill Khadr's rights as its citizens when he was still a child who needed an supportive and condusive environment to shape his behavior and character. The restitution and rehabilitation done by Canada is nothing but to make amends for State's failure to protect Khadr's rights when he was a child.

According to Human Right Watch, if Khadr and Jawad were punished, then the sentences sent to them must pay attention to: lack of independence, relative culpability, and vulnerability to outside influence as a child'. The CRC which the United States is a signatory requires " imprisonment of a child shall be in conformity with the law and shall be used only as a measure of last resort and for the shortest appropriate period of time." 86 This shows that their condition when they become child soldiers has claimed their inherent rights and imprisonment is not in favour of their best interest.

In this case it is the opposite of the school adopted by the International Criminal Court. . The ICC judge tends to adopt the school of indeterminism which argued that Ongwen has free will on the choice of whether he will commit an evil deed and also considers that the influences obtained by Ongwen while he was still a child soldier did not affect his evil deeds in the future. The author actually considers that the crimes committed by former child soldiers are a form of the influence of the treatments that they have forcibly received as long as they are forced to serve in a hard (determinant) military environment. The author assumes that this can be proven by the fact that not all child soldiers end up like Ongwen, many of them who finally survived or were saved have to pay the price after spending time under such circumstances which affects their wellbeing, physically and psychologically. These circumstances are what made Ongwen and other child soldiers as they are today.

\section{E. CONCLUSION}

Until now, the ICC has not considered yet whether the history of someone who was a child soldier could exclude him from criminal responsibility. In imposing a sentence, the ICC Judge only considers the gravity of crime, the personal condition of the defendant, and the ability of the perpetrator to be responsible. Currently, the case of Dominic Ongwen is still in the Trial stage and has not been decided. However, based at the common practice of the ICC, the Court will not consider the history of Dominic Ongwen as a former child soldier. However, based on Article 21 of the Rome Statute on the legal basis, the International Criminal Court Judge has the discretion to use legal sources beyond the Rome Statute, including national law and national court decisions, such as the Canadian Court which considers the history of Omar Khadr who has the same history as Dominic Ongwen, namely as a child soldier.

\footnotetext{
86 Human Right Watch, "Omar Khadr: Military Commission Trial of Ex-Child Soldier," https://www.hrw.org/sites/default/files/related material /Omar\%20Khadr\%20Q\%26A.pdf accessed at $16^{\text {th }}$ of April 2018.
}

\footnotetext{
5 Reuters, "U.S. judge orders Guantanamo prisoner Jawad freed," https://www.reuters.com/article/us-guantanamojawad/u-s-judge-orders-guantanamo-prisoner-jawadfreed-idUSTRE56S7H120090730. accessed at 7th of February 2018.
} 
Such Discretion possessed by The ICC Judge should be able to be used by the judges to protect the perpetrators of international crimes that were actually victims in the past. The writer has tried to open up other possibilities that have been implemented in several countries. It is intended for justice at the ICC as a permanent institution authorized to prosecute the perpetrators and provide victims with protection and security. While the Dominic Ongwen case has not yet been decided, consideration outside the International Criminal Court can be seen to be used to consider a history of someone who was a child soldier.

\section{REFERENCES}

\section{Books}

Beah, Ishmael, A Long Way Gone: Memoirs of a Boy Soldier, New York: Sarah Crichton Books, 2007.

Bassiouni, M. Cherif and Schabas, William A., The Legislative History of the International Criminal Court, New York: Transnational Publishers, Inc., 2005.

Bobzien, Susanne, Determinism and Freedom in Stoic Philosophy, New York: Oxford Press University, 1998.

Chinkin, Christine and Baetens, Freya, Sovereigny, Statehood, and States Responsibility, United Kingdom: Cambridge University Press, 2015.

Cohn, Ilene and Goodwin-Gill, Guy S., Child Soldier: The Role of Children in Armed Conflict, Oxford: Clarendon Press, 1997.

Dumblr, Mark A., Reimagining Child Soldiers in International Law and Policy, Oxford: Oxford University Press, 2012,.

Flowers, Ronald B., Children and Criminality: The Child as Victim and Perpetrator, Connecticut: Greenwood Press.

Honwana, Alcinda, Child Soldiers in Africa, Pennsylvania: University of Pennsylvania Press, 2005.
Grover, Sonja C., Child Soldier Victims of Genocidal Forcible Transfer: Exonerating Child Soldiers Charged with Grave Conflictrelated International Crimes, Ontario: Springer, 2012.

Kuper, Jenny, International Law Conerning Child Civilians in Armed Conflict, Oxford: Clarendon Press, 1997.

Jenings, Mark in Triffterer, Otto et.al, Commentary on the Rome Statute of the International Criminal Court, Munich: Nomos Verlagsgesselschaft, 1999.

Moffett, Luke, Justice for Victims before the International Criminal Court, London: Routledge, 2014.

Monach, James H., Childless: No Choice: The Experience of Involuntary Childlessness, London: Routledge, 2006.

Okpaku, Samuel O., Essentials of Global Mental Health, New York: Cambridge University Press, 2014,

Shadia B. Drury, "Omar Khadr and the Perils of Canadian Multiculturalism" in Omar Khadr, Oh Canada, Ontario: Mc.Gill Queens University Press, 2012

Snephard, Michelle, Guantanamo's Child: The Untold Story of Omar Khadr, Ontario: John Wiley \& Sons Canada Ltd, 2008.

Supriyadi W. Eddyono, S.H, Seri Bahan Bacaan Kursus HAM untuk Pengacara XI Tahun 2007, Jakarta: Lembaga Studi and Advokasi Masyarakat, 2007.

Sweet, William, Philosophical Theory and the Universal Declaration of Human Rights, Canada: University of Ottawa Press, 200.

The National Counter Terrorism Center, Counter Terrorism 2016 Calendar, United States Counter Terrorism Center, p. 86.

Williamson, Janice, Omar Khadr, Oh Canada, Ithaca: McGill-Queen's University Press, 2012.

\section{Other Documents}

Baines, Erin K. "Complex political perpetrators: reflections on Dominic 
Fomer Child Soldiers: Product of Armed Conflicts and How the International Criminal

Court Fails to See Its Significance

Ongwen", The Jou[rnal of Modern African Studies, Volume 47, Issue 2, 2009.

Beber, Bernd and Blattman, Christopher, "The Logic of Child Soldiering and Coercion", International Organization, Volume 67, Issue 1, January 2013, p. 65-104.

Chimpreports, "KCC - Cosmos De Bafia (Cameroon) ticketing info", https://chimpreports.com/kcc-cosmosde-bafia-cameroon-ticketing-info/ accessed at $9^{\text {th }}$ of September 2018.

Daily Monitor, "Wife, Children to Visit Ongwen,"

http://www.monitor.co.ug/News/Nationa I/Wife-children-visit-Ongwen/6883343479100-va6mb7z/index.html. Accessed at $28^{\text {th }}$ of March 2018.

Dillard, Carter, "Prospective Parents and the Children's Rights Convention", American University International Law Review, Volume 25, Issue 3, 2010, p. 499-500.

Fagan, Tyler et.al, "Child Soldiers, Executive Functions, and Culpability", International Criminal Law Review, Volume 16, No. 2, 2016.

Francis Ssekandi and Netsanet Tesfay, "Engendered Discontent: The International Criminal Court in Africa", Georgetown Journal of International Affairs: Vol XVIII, No.1, 2017, p. 86.

Human Right Watch, "Omar Khadr: Military Commission Trial of Ex-Child Soldier," https://www.hrw.org/sites/default/files/r elated material/Omar\%20Khadr\%20Q\%2 6A.pdf accessed at $16^{\text {th }}$ of April 2018.

Human Right Watch, "United States of America: Compliance with the Optional Protocol to the Convention on the Rights of the Child on the involvement of children in armed conflict", https://www.hrw.org/sites/default/files/s upporting resources/us opac review 2017 hrw submission.pdf downloaded at 15 of April 2018.
Interview with Judge Raul C. Pangalangan on 24 July 2018, 18.00 WIB in Bandung, Indonesia

Jikia, Mariam, "Individual Criminal Responsibility According to Article 25 of ICC Statute", Scientific-Practical and Reviewed Journal "Justice", Vol. 3, 2008, p. 4.

JURIST Legal News, "The Omar Khadr Case: Redefining War Crimes", http://jurist.law.pitt.edu/omar-khadrcase-redefining-war-crimes.php, accessed at $30^{\text {th }}$ June 2018.

Kaplan, Eben, "Child Soldiers Around the World",

https://www.cfr.org/backgrounder/childsoldiers-around-world, downloaded on the $28^{\text {th }}$ of January 2017 The Washington Post, "The zombie claim that 300,000 children are used as child soldiers," https://www.washingtonpost.com/news/ fact-checker/wp/2016/01/22/thezombie-claim-that-300000-children-areused-as-childsoldiers/?utm term=.e8f7b5e1c8df, accessed on $7^{\text {th }}$ of February 2017; Independent, "300,000 child soldiers in front line", https://www.independent.co.uk/news/30 0000-child-soldiers-in-front-line-

1046382.html, accessed at $7^{\text {th }}$ of February 2017; Forbes, "For Child Soldiers, Every Day Is A Living Nightmare", https://www.forbes.com/sites/realspin/2 012/12/09/for-child-soldiers-every-day-isa-living-nightmare $/$ accessed at $7^{\text {th }}$ of February 2017.

Kasande, Sarah Kihika and Ladisch, Virginie, "The Complex Reality Beyond the Trial of Dominic Ongwen", https://www.ictj.org/news/complex-iccongwen. Accessed on $25^{\text {th }}$ of March 2018.

Kihika, Sarah, "The Complex Reality beyond the Trial of Dominic Ongwen", https://www.ictj.org/news/complex-icc- 
ongwen accessed on $3^{\text {rd }}$ of September 2018.

National Public Radio, "A Former Child Soldier Finds Escape, Heaven Through His Music", https://www.npr.org/sections/goatsands oda/2015/01/29/382482527/a-formerchild-soldier-finds-escape-heaventhrough-his-music, accessed at $9^{\text {th }}$ of February 2017.

Navaneelan, Tony and Oja, Kate, "The United States v. Omar Khadr, Pre-Trial Observation Report," https://www.law.utoronto.ca/documents Lihrp/Khadr - Pre-

Trial Observation Report FINAL March 2009.pdf accessed at $22^{\text {nd }}$ of October, 2018.

NN, "Ex-child-soldier: Shooting became just like drinking a glass of water", https://edition.cnn.com/2012/10/08/wor Id/africa/ishmael-beah-childsoldier/index.html accessed at $8^{\text {th }}$ of February 2017;

Reuters, "U.S. judge orders Guantanamo prisoner Jawad freed," https://www.reuters.com/article/usguantanamo-jawad/u-s-judge-ordersguantanamo-prisoner-jawad-freedidUSTRE56S7H120090730. accessed at 7th of February 2018.

Schmidt, Alice, "Volunteer Child Soldiers as Reality: A Development Issue for Africa", New School Economic Review, Volume 2(1), 2007.

Singers, W., "Caution: Children at War", Journal of the US Army War College, Volume 31, No. 4, 2002

Turner, Jenialontcheva, "Plea Bargaining and International Criminal Justice", The University of the Pacific Law Review, Vol. 48, p. 238.Child Soldier International, "Child Soldiers International Annual Report 2017-2018", https://www.childsoldiers.org/Handlers/Download.ashx?ID $\mathrm{MF}=841 \mathrm{fa} 200-9315-4 \mathrm{e} 8 \mathrm{a}-9 \mathrm{a} 6 \mathrm{c}-$ cdf63a0af22a , accessed on February 2018.

Women's Initiatives for Gender Justice, "First ICC Trial in the Uganda Situation the Prosecutor v. Dominic Ongwen 5 December 2016", https://4genderjustice.org/pub/First-ICCTrial-in-Uganda-Situation-Statement.pdf accessed at 21st of March 2018.

\section{Legal Documents}

Canada (Prime Minister) v. Omar Khadr, Decision of the Canadian Supreme Court, 1 S.C.R. 44, 2010.

ICC, "ICC Pre-Trial Chamber II confirms the charges against Dominic Ongwen and commits him to trial", https://www.icccpi.int/Pages/item.aspx?name=pr1202 accessed on $23^{\text {rd }}$ of March 2018.

ICC, Prosecutor v. Dominic Ongwen (Pre-Trial Chamber), Decision on the confirmation of charges 2016, para 25.

ICC, Presecutor v. Thomas Lubanga Dyilo (Trial Chamber), Reparation and Compensation, 2012, para. 574.

ICC, Prosecutor v. Dominic Ongwen (Pre-Trial Chamber), Decision on the confirmation of charges against Dominic Ongwen, 2016, para. 120.

ICC, Prosecutor v. Dominic Ongwen (Pre-Trial Chamber), Decision on the confirmation of charges against Dominic Ongwen, 2016, para. 121.

ICC, Prosecutor v. Dominic Ongwen (Pre-Trial Chamber), Decision on the confirmation of charges against Dominic Ongwen, 2016, para. 150

ICC, Prosecutor v. Dominic Ongwen (Pre-Trial Chamber), Defence Request for Leave to Appeal the Oral Decision of 6 December 2016 on Mr Ongwen's Understanding of the Nature of the Charges, 2016, para. 67.

ICC, Prosecutor v. Dominic Ongwen (Trial Chamber), Prosecution's Response to "Defense Request for Leave to Appeal the 
Fomer Child Soldiers: Product of Armed Conflicts and How the International Criminal

Court Fails to See Its Significance

Oral Decision of 6 December 2016 on $\mathrm{Mr}$

Ongwen's Understanding of the Nature of the Charges", 2016, p. 6

ICC, Prosecutor v. Dominic Ongwen (Trial Chamber), Statement of the Prosecutor of the International Criminal Court, Fatou Bensouda, at the opening of Trial in the case against Dominic Ongwen, 2016.

ICC, Prosecutor v. Lubanga (Pre-Trial Chamber), Decision concerning Pre-Trial Chamber I's Decision of 10 February 2006 and the Incorporation of Documents into the Record of the Case against Mr Thomas Lubanga Dyilo, 2006, paras. 42- 60; See ICC, Prosecutor v. Abu Garda (Pre-Trial Chamber), Decision on the Confirmation of Charges, 2010, para. 31.

ICC, Prosecutor v.Dominic Ongwen (Pre-Trial Chamber), Decision on the confirmation of charges against Dominic Ongwen, 2016, Para 32

ICTY, Prosecutor v. Dragoljub Kunarac, Radomir Kovac \& Zoran Vuković (Trial Chamber) Judgment, 2001, para. 863.

ICTY, Prosecutor v. Vasiljevic (Appeals Chamber), Judgment, 2004, para. 182; ICTY, Prosecutor v. Krstic (Appeals Chamber), Judgment, 2004, para. 268 